\title{
Kinetics and Efficiency of $\mathrm{H}_{2} \mathrm{O}_{2}$ Activation by Iron-Containing Minerals and Aquifer Materials
}

\author{
Anh Le-Tuan Pham ${ }^{1}$, Fiona M. Doyle ${ }^{2,}$, and David L. Sedlak ${ }^{1,}$ \\ ${ }^{1}$ Department of Civil and Environmental Engineering, University of California at Berkeley \\ Berkeley, California 94720 \\ ${ }^{2}$ Department of Materials Science and Engineering, University of California at Berkeley Berkeley, \\ California 94720
}

\section{Abstract}

To gain insight into factors that control $\mathrm{H}_{2} \mathrm{O}_{2}$ persistence and ${ }^{\circ} \mathrm{OH}$ yield in $\mathrm{H}_{2} \mathrm{O}_{2}$-based in situ chemical oxidation systems, the decomposition of $\mathrm{H}_{2} \mathrm{O}_{2}$ and transformation of phenol were investigated in the presence of iron-containing minerals and aquifer materials. Under conditions expected during remediation of soil and groundwater, the stoichiometric efficiency, defined as the amount of phenol transformed per mole of $\mathrm{H}_{2} \mathrm{O}_{2}$ decomposed, varied from 0.005 to $0.28 \%$. Among the iron-containing minerals, iron oxides were 2 to 10 times less efficient in transforming phenol than iron-containing clays and synthetic iron-containing catalysts. In both iron-containing mineral and aquifer materials systems, the stoichiometric efficiency was inversely correlated with the rate of $\mathrm{H}_{2} \mathrm{O}_{2}$ decomposition. In aquifer materials systems, the stoichiometric efficiency was also inversely correlated with the Mn content, consistent with the fact that the decomposition of $\mathrm{H}_{2} \mathrm{O}_{2}$ on manganese oxides does not produce ${ }^{\circ} \mathrm{OH}$. Removal of iron and manganese oxide coatings from the surface of aquifer materials by extraction with citrate-bicarbonate-dithionite slowed the rate of $\mathrm{H}_{2} \mathrm{O}_{2}$ decomposition on aquifer materials and increased the stoichiometric efficiency. In addition, the presence of $2 \mathrm{mM}$ of dissolved $\mathrm{SiO}_{2}$ slowed the rate of $\mathrm{H}_{2} \mathrm{O}_{2}$ decomposition on aquifer materials by over $80 \%$ without affecting the stoichiometric efficiency.

\section{Keywords}

Fenton reaction; advanced oxidation process; groundwater treatment; iron oxides; hydrogen peroxide; dissolved silica

\section{Introduction}

Over the past two decades, hydrogen peroxide-based in situ Chemical Oxidation (ISCO) has become increasingly popular as a means of remediating contaminated soil and groundwater (Huling and Pivetz, 2006; Krembs et al., 2010). In this practice, concentrated solutions of

\footnotetext{
(C) 2012 Elsevier Ltd. All rights reserved

*Address correspondence to either author: Fiona Doyle, Department of Materials Science and Engineering, 320 McLaughlin Hall, University of California, Berkeley, Berkeley CA 94720-1700. Phone: +1-510-642-5771. Fax: +1-510-642-9178. fmdoyle@berkeley.edud David Sedlak, Department of Civil and Environmental Engineering, 657 Davis Hall, University of California, Berkeley, Berkeley CA 94720-1710. Phone: +1-510-643-0256. Fax: +1-510-642-7483. sedlak@berkeley.edu.

Publisher's Disclaimer: This is a PDF file of an unedited manuscript that has been accepted for publication. As a service to our customers we are providing this early version of the manuscript. The manuscript will undergo copyediting, typesetting, and review of the resulting proof before it is published in its final citable form. Please note that during the production process errors may be discovered which could affect the content, and all legal disclaimers that apply to the journal pertain.
} 
$\mathrm{H}_{2} \mathrm{O}_{2}$ are injected into groundwater or added to soils. Upon contacting iron-containing minerals, some of the $\mathrm{H}_{2} \mathrm{O}_{2}$ is converted into ${ }^{\circ} \mathrm{OH}$ (reaction 1 and 2 (e.g., Lin and Gurol, 1998; Petigara et al., 2002)), which subsequently oxidizes contaminants. The technology is effective against many of the most recalcitrant organic contaminants typically encountered at contaminated sites (e.g., benzene, phenol, trichloroethylene, polycyclic aromatic hydrocarbons). The use of $\mathrm{H}_{2} \mathrm{O}_{2}$ is also attractive because it is relatively inexpensive and its byproducts, namely $\mathrm{O}_{2}$ and $\mathrm{H}_{2} \mathrm{O}$, are benign.

$$
\begin{aligned}
& \equiv \mathrm{Fe}(\mathrm{III})+\mathrm{H}_{2} \mathrm{O}_{2} \rightarrow \equiv \mathrm{Fe}(\mathrm{II})+\mathrm{O}_{\mathbf{2}}{ }^{\bullet-}+\mathbf{2 H}^{+} \\
& \equiv \mathrm{Fe}(\mathrm{II})+\mathrm{H}_{2} \mathrm{O}_{2} \rightarrow \equiv \mathrm{Fe}(\mathrm{III})+{ }^{\bullet} \mathrm{OH}+\mathrm{OH}^{-} \\
& 2 \mathrm{H}_{2} \mathrm{O}_{2} \stackrel{\mathrm{Fe}-\text { and } \mathrm{Mn}-\text { oxides, } \quad \text { enzymes }}{\longrightarrow} \mathrm{H}_{2} \mathrm{O}+\mathrm{O}_{2}
\end{aligned}
$$

The cost and efficiency of $\mathrm{H}_{2} \mathrm{O}_{2}$-based ISCO systems depend largely upon the distance that $\mathrm{H}_{2} \mathrm{O}_{2}$ travels in the subsurface, as well as the fraction of the $\mathrm{H}_{2} \mathrm{O}_{2}$ that is converted into 'OH. It is generally desirable that $\mathrm{H}_{2} \mathrm{O}_{2}$ persists in the subsurface for a significant amount of time so that it can penetrate deep into aquifers and react with contaminants distant from injection wells. Thus, conditions that maximize $\mathrm{H}_{2} \mathrm{O}_{2}$ persistence in the subsurface are usually desirable, because they minimize both the amount of $\mathrm{H}_{2} \mathrm{O}_{2}$ and the number of injection wells needed to decontaminate a given site. $\mathrm{As}_{2} \mathrm{O}_{2}$ also can be decomposed by non-radical pathways (i.e., the pathways that do not produce ${ }^{\circ} \mathrm{OH}$, which are represented collectively by reaction 3) (Petigara et al., 2002; Pham et al., 2009), the amount of $\mathrm{H}_{2} \mathrm{O}_{2}$ required also depends upon the yield of ' $\mathrm{OH}$ (i.e., the relative amount of $\mathrm{H}_{2} \mathrm{O}_{2}$ decomposed by reaction 1 and 2 to the total amount of $\mathrm{H}_{2} \mathrm{O}_{2}$ decomposed by reaction $1-3$ ).

To gain insight into factors that influence $\mathrm{H}_{2} \mathrm{O}_{2}$ persistence and ' $\mathrm{OH}$ yield, previous investigators have studied $\mathrm{H}_{2} \mathrm{O}_{2}$ decomposition and contaminant transformation in systems consisting of pure iron oxides (e.g., ferrihydrite, hematite and goethite (Valentine and Wang, 1998; Huang et al., 2001; Kwan and Voelker, 2002)), iron minerals (e.g., pyrite (Matta et al., 2007), iron-containing aluminosilicates (e.g., Luo et al., 2009)), and aquifer materials and soils (Ravikumar and Gurol, 1994; Miller and Valentine, 1999; Petigara et al., 2002; Bissey et al., 2006; Watts et al., 2007; Xu and Thomson, 2010). Although these studies help explain the trends in the rates of removal of contaminants in groundwater and sediments upon addition of $\mathrm{H}_{2} \mathrm{O}_{2}$, it is still difficult to predict the rates of these processes under conditions encountered at hazardous waste sites.

Studies conducted with pure minerals have suggested that the crystallinity of the oxide, the coordination of $\mathrm{Fe}$, and the mineral surface area affect $\mathrm{H}_{2} \mathrm{O}_{2}$ decomposition rates and ${ }^{\circ} \mathrm{OH}$ yields (Valentine and Wang, 1998; Huang et al., 2001). Nevertheless, these studies are of limited utility because iron in aquifer materials usually exists as a mixture of different phases and/or is associated with other oxides (e.g., silica, alumina or manganese oxides). The reactivity of oxides in mixed oxides and silicates is different from that of the constituent end-member minerals (Lim et al., 2006; Pham et al., 2009; Taujale and Zhang, 2012). Moreover, in addition to iron minerals, other components in soils, such as manganese oxides, organic matter, and enzymes (e.g., catalase or peroxidase), also serve as $\mathrm{H}_{2} \mathrm{O}_{2}$ sinks (Petigara et al., 2002; Xu and Thomson, 2010). Thus, results obtained with iron oxides and iron minerals do not capture the heterogeneity and complexity of sediment systems, and could overestimate the production ${ }^{\circ} \mathrm{OH}$ in remediation systems. Although studies conducted with aquifer materials and soils have the potential to capture some of this heterogeneity, 
most previous studies have not related rates of $\mathrm{H}_{2} \mathrm{O}_{2}$ decomposition and ${ }^{\circ} \mathrm{OH}$ yields to the surface properties of the sediments. For example, Xu and Thomson (2010) attempted to correlate the rate of $\mathrm{H}_{2} \mathrm{O}_{2}$ decomposition with aquifer materials' properties. Their results suggested that the $\mathrm{H}_{2} \mathrm{O}_{2}$ decomposition rate is correlated with the $\mathrm{Fe}$ and $\mathrm{Mn}$ content of the aquifer materials. However, they did not quantify ${ }^{\circ} \mathrm{OH}$ yields. Thus, it is currently difficult to predict the performance of $\mathrm{H}_{2} \mathrm{O}_{2}$-based ISCO treatment systems without conducting extensive site-specific scoping studies. Hence, more research is needed to predict and optimize contaminant removal in $\mathrm{H}_{2} \mathrm{O}_{2}$-based ISCO treatment system.

To reconcile prior observations of the role of different types of transition metal catalysts with data on stoichiometric efficiency and $\mathrm{H}_{2} \mathrm{O}_{2}$ activation kinetics, the reactivity of various iron-containing minerals and a diverse set of aquifer materials have been investigated. By studying $\mathrm{H}_{2} \mathrm{O}_{2}$ activation with materials from ten different aquifers under similar conditions (i.e., well-buffered solution $\mathrm{pH}$ and identical initial concentration of $\mathrm{H}_{2} \mathrm{O}_{2}$ and target contaminant) and correlating results with data on materials' physico-chemical properties, new insight has been gained about the factors affecting the $\mathrm{H}_{2} \mathrm{O}_{2}$ decomposition rates and ' $\mathrm{OH}$ yields. To assess the role of free iron and manganese oxides (i.e., pure oxides that exist as discrete particles or as surface coatings), aquifer materials were leached with citratebicarbonate-dithionite (CBD) solution to remove both types of metal-oxide coatings prior to $\mathrm{H}_{2} \mathrm{O}_{2}$ addition. In addition, the effect of dissolved $\mathrm{SiO}_{2}$, a solute that is ubiquitous in groundwater, on the reactivity of aquifer materials was also studied.

\section{Materials and Methods}

\subsection{Chemicals}

All chemicals were reagent grade and were used without further purification. Solutions were prepared using $18 \mathrm{M} \Omega$ Milli-Q water from a Millipore system.

\subsection{Iron-containing minerals}

Amorphous iron oxyhydroxide 50 - 80 mesh (i.e., amorphous Fe-oxide, obtained from Adrich) was ground using a mortar and pestle prior to sieving through a $150-\mu \mathrm{m}$ sieve. Goethite and hematite were synthesized by aging freshly made ferrihydrite in a concentrated $\mathrm{NaOH}$ solution at $70^{\circ} \mathrm{C}$ for 60 hours (goethite synthesis) or at $\mathrm{pH} 8$ to 8.5 in the presence of $\mathrm{NaHCO}_{3}$ at $90{ }^{\circ} \mathrm{C}$ for $48 \mathrm{~h}$ (hematite synthesis) (Schwertmann and Cornell, 2006). Two types of 2:1 iron-containing clay, namely Wyoming Montmorillonite (Swy-2, 2.59\% Fe by weight) and Australian Nontronite (NAu-2, 26.04\% Fe by weight), were obtained from the Source Clays Repository (The Clay Minerals Society). Fine powder Swy-2 was used as received, while large chunks of NAu-2 were ground using a shatter box prior to sieving through a $150-\mu \mathrm{m}$ sieve. Iron oxide-coated sand $\left(1 \% \mathrm{Fe}\right.$ by weight, $\left.4.8 \mathrm{~m}^{2} / \mathrm{g}\right)$ was kindly provided by Peter Nico (Lawrence Berkeley National Laboratory). The synthesis and characterization of iron oxide-coated sand have been reported elsewhere (Nico et al., 2009). FeSi-ox and FeAlSi-ox catalysts were synthesized following the procedure reported previously (Pham et al., 2009). The surface area of these minerals, determined using the 5point BET (Brunauer-Emmett-Teller) nitrogen physisorption method, is reported in Table 1.

\subsection{Aquifer materials}

Aquifer materials were obtained from 10 aquifers located in California (CADIR, CADOU, CADMS, CAROL), Arizona (AWBPH, AFTCS, AMTAL), Wyoming (WYSAN, WYLAM), and Kentucky (KENTK). Samples were dried, homogenized, and sieved through a $600-\mu \mathrm{m}$ sieve. The $600-\mu \mathrm{m}$ fractions were used in the phenol oxidation experiments (section 2.5). Their physico-chemical properties are reported in Table 2. 


\subsection{Treatment of aquifer materials with citrate-bicarbonate-dithionite solution}

Samples of six selected aquifer materials (i.e., CADIR, CADOU, AFTCS, AWBPH, WYLAM, and WYSAN) were treated with citrate-bicarbonate-dithionite (CBD) solution prior to the phenol oxidation experiment. The CBD treatment removes primarily pure iron and manganese oxides that exist as discrete particles or as coatings on the surface of aquifer materials, but not structural iron and manganese incorporated in silicates or aluminosilicates (Kunze and Dixon, 1986). The amount of CBD-extractable Fe and $\mathrm{Mn}$ in the aquifer materials is reported in Table 2. Details on the CBD treatment procedure are reported in Section 1 of the supporting information section.

\subsection{Hydrogen peroxide decomposition and phenol transformation}

$\mathrm{H}_{2} \mathrm{O}_{2}$ decomposition and phenol transformation experiments were conducted in the dark in a 150-mL Pyrex flask that was shaken at $200 \mathrm{rpm}$. Phenol was selected as a model target contaminant because it is not significantly adsorbed by any of the solids and reacts with ${ }^{\circ} \mathrm{OH}$ at a near-diffusion controlled rate. Each flask contained $10 \mathrm{~mL}$ of a solution consisting of $250 \mathrm{mM} \mathrm{H}_{2} \mathrm{O}_{2}$ and $0.5 \mathrm{mM}$ phenol, with $1-10 \mathrm{~g} / \mathrm{L}$ of iron-containing minerals or $50-150$ $\mathrm{g} / \mathrm{L}$ of aquifer materials. Suspensions were buffered with $2-10 \mathrm{mM}$ borate. The initial $\mathrm{pH}$ of the suspensions was 8.4 and did not vary by more than $0.3 \mathrm{pH}$ unit over the course of the experiment, with the exception of the KENTK materials, where the $\mathrm{pH}$ dropped quickly to 7.2 and remained stable during the experiment. Reactors were open to the atmosphere but were covered with parafilm to minimize evaporation.

Samples were withdrawn at predetermined time intervals and divided into two aliquots. The first aliquot was centrifuged to separate the solids, then the supernatant was filtered immediately through a $0.2-\mu \mathrm{m}$ nylon filter prior to analysis for $\mathrm{H}_{2} \mathrm{O}_{2}$. Acetonitrile was added to the second aliquot (acetonitrile:sample $=1: 1$ ) and the mixture was agitated vigorously for 2 minutes with a vortex mixer to extract phenol from the solids. The solids were then separated by centrifugation and filtration, and the solution was analyzed for phenol. Phenol recovery by acetonitrile extraction was always above $98 \%$ in $\mathrm{H}_{2} \mathrm{O}_{2}$-free controls. The stoichiometric efficiency, E, defined as the amount of phenol transformed per mole of hydrogen peroxide decomposed (i.e., $\mathrm{E}=\frac{\Delta[\text { phenol }]}{\Delta\left[\mathrm{H}_{2} \mathrm{O}_{2}\right]} \times 100 \%$ ), was used to compare the $\mathrm{H}_{2} \mathrm{O}_{2}$ activation efficiency for different solids (Pham et al., 2009). All experiments were carried out at $22 \pm 2^{\circ} \mathrm{C}$ and at least in triplicate, and the average results were reported together with one standard deviation.

\subsection{Analytical methods}

Phenol was analyzed using HPLC as described previously (Pham et al., 2009). $\mathrm{H}_{2} \mathrm{O}_{2}$ was analyzed spectrophotometrically by the titanium sulfate method (Eisenberg, 1943). Total dissolved iron was quantified using the 1,10-phenanthroline method after adding hydroxylamine hydrochloride to the filtered samples (Tamura et al., 1974). The concentration of dissolved iron was always below the detection limit (i.e., less than $5 \mu \mathrm{M}$ ).

\section{Results and discussions}

\section{1. $\mathrm{H}_{2} \mathrm{O}_{2}$ decomposition, phenol oxidation, and stoichiometric efficiency}

a. Iron-containing minerals-Under the conditions employed in the experiments, $\mathrm{H}_{2} \mathrm{O}_{2}$ and phenol disappeared from the suspensions over a period of several days (Figure 1A). No phenol loss was observed in the absence of $\mathrm{H}_{2} \mathrm{O}_{2}$ or in the presence of $100 \mathrm{mM}$ tert-butanol (an ${ }^{\circ} \mathrm{OH}$ scavenger). These results collectively suggested that phenol was lost from systems containing minerals and $\mathrm{H}_{2} \mathrm{O}_{2}$ through the reaction with ${ }^{\circ} \mathrm{OH}$. Furthermore, ${ }^{\circ} \mathrm{OH}$ production 
in these systems was mainly attributable to surface-catalyzed reactions because the concentration of dissolved iron was always below the detection limit (i.e., less than $5 \mu \mathrm{M}$ ).

The stoichiometric efficiency in the iron-containing mineral/ $\mathrm{H}_{2} \mathrm{O}_{2}$ systems varied over an order of magnitude, from $0.02 \%$ with amorphous Fe-oxide to $0.25 \%$ with FeAlSi-ox (Figure 1B). The low stoichiometric efficiency suggests that the majority of the $\mathrm{H}_{2} \mathrm{O}_{2}$ (i.e., more than $99 \%$ ) was decomposed via reactions that do not produce $\mathrm{OH}$ (Petigara et al., 2002; Pham et al., 2009). Consistent with our previous study (Pham et al., 2009), the stoichiometric efficiency was higher for the iron silicates and aluminosilicates (FeSi-ox, FeAlSi-ox, NAu-2 and Swy-2) than for the pure iron oxides. This was most likely attributable to the Fe coordination environment in the silicates and aluminosilicates, which favored $\mathrm{H}_{2} \mathrm{O}_{2}$ decomposition via the radical mechanisms (reaction 1 and 2) over the nonradical mechanisms (reaction 3) (Pham et al, 2009). The stoichiometric efficiency also appeared to be inversely correlated with the rate of $\mathrm{H}_{2} \mathrm{O}_{2}$ decomposition, with lower stoichiometric efficiency occurring mainly in systems with faster $\mathrm{H}_{2} \mathrm{O}_{2}$ decomposition (Figure 1 and Table 1).

Both FeSi-ox and iron oxide-coated sand contained Fe and Si. Under the experimental conditions employed in this study, however, FeSi-ox was approximately 5 times more effective than iron oxide-coated sand in $\mathrm{H}_{2} \mathrm{O}_{2}$ activation (stoichiometric efficiency of 0.24 and $0.045 \%$ for FeSi-ox and iron oxide-coated sand, respectively (Figure 1B)). The higher efficiency of the FeSi-ox catalyst might also be attributable to the difference in $\mathrm{Fe}$ coordination environment in each solid. In the case of iron oxide-coated sand, sand particles were coated with ferrihydrite slurry (Nico et al., 2009) whereas the FeSi-ox was synthesized by a sol-gel process, in which a mixture of tetraethyl orthosilicate (a silica precursor) and dissolved $\mathrm{Fe}^{3+}$ was coprecipitated in a strong alkaline solution (Pham et al., 2009). For FeSiox, the coordination of Fe by silicate and/or close interaction between Fe and Si might have created surface conditions that were more favorable for ${ }^{\circ} \mathrm{OH}$ production during $\mathrm{H}_{2} \mathrm{O}_{2}$ decomposition (Pham et al., 2009).

While NAu-2 and Swy-2 are both 2:1 layered smectites, the stoichiometric efficiency with NAu-2 (0.21\%) was almost double that with Swy-2 (0.12\%). Compared with other 2:1 clays, $\mathrm{NAu}-2$ contains a significantly higher concentration of Fe in the octahedral layer (Keeling et al., 2000). The potential for structural iron to produce higher ${ }^{\circ} \mathrm{OH}$ yields when used as a heterogeneous catalyst warrants further investigation. Additionally, detailed study on the correlation between the structure of well-characterized clays and their potential to produce $\cdot \mathrm{OH}$ from $\mathrm{H}_{2} \mathrm{O}_{2}$ might provide further insight into the reaction mechanism, as well as a basis for synthesizing more effective catalysts for $\mathrm{H}_{2} \mathrm{O}_{2}$-based ex situ oxidative treatment.

b. Aquifer materials-The catalytic activity of aquifer materials with respect to $\mathrm{H}_{2} \mathrm{O}_{2}$ activation was investigated using an approach similar to that employed for iron-containing minerals. In the aquifer materials $/ \mathrm{H}_{2} \mathrm{O}_{2}$ systems, phenol and $\mathrm{H}_{2} \mathrm{O}_{2}$ loss by dissolved metalcatalyzed reactions were negligible compared with those catalyzed by the surface of the materials (see Section 2 in the supporting information section for a detailed explanation). Phenol loss was attributable mainly to oxidation by ${ }^{\circ} \mathrm{OH}$, as no phenol loss was observed in the presence of $100 \mathrm{mM}$ tert-butanol or in the absence of $\mathrm{H}_{2} \mathrm{O}_{2}$. This also suggests that phenol loss in the presence of $\mathrm{H}_{2} \mathrm{O}_{2}$ was not due to a biological transformation reaction. Note that aquifer materials were not sterilized and, therefore, it is possible that some of the $\mathrm{H}_{2} \mathrm{O}_{2}$ was decomposed by enzymes.

The stoichiometric efficiency of phenol oxidation for aquifer materials (Figure 2B) spanned the range observed with iron minerals (Figure 1B), with a stoichiometric efficiency of $0.28 \%$ with the KENTK sample and $0.005 \%$ with the WYLAM sample (Figure 2B). The KENTK 
sample was tested at a $\mathrm{pH}$ value of 7.2, which was lower than the $\mathrm{pH}$ values used for the other materials. Previous experiments have shown that the stoichiometric efficiency increases as pH decreases (Pham et al., 2009).

As observed for the iron-containing minerals, the stoichiometric efficiency was in general inversely correlated with the rate of $\mathrm{H}_{2} \mathrm{O}_{2}$ decomposition (Figure $2 \mathrm{~A}$ and $2 \mathrm{~B}$ ), with samples that were more reactive toward $\mathrm{H}_{2} \mathrm{O}_{2}$ decomposition exhibiting lower stoichiometric efficiencies. A similar relationship between $\mathrm{H}_{2} \mathrm{O}_{2}$ decomposition rates and ${ }^{\circ} \mathrm{OH}$ yields was reported by Petigara et al. (2002), who postulated the existence of two competing $\mathrm{H}_{2} \mathrm{O}_{2}$ decomposition pathways, with the pathway that does not produce $\mathrm{OH}$ being more important in soils with higher $\mathrm{H}_{2} \mathrm{O}_{2}$ decomposition rates.

The reactivity of aquifer materials with $\mathrm{H}_{2} \mathrm{O}_{2}$ is likely related to their physico-chemical properties, especially the iron and manganese oxide content. To gain insight into the relative importance of iron and manganese oxides in $\mathrm{H}_{2} \mathrm{O}_{2}$ activation, we investigated the relationship between the amount of these oxides in the samples and the rates of $\mathrm{H}_{2} \mathrm{O}_{2}$ loss and yields of ${ }^{\prime} \mathrm{OH}$. The decomposition of $\mathrm{H}_{2} \mathrm{O}_{2}$ on iron and manganese oxides has been widely reported to exhibit a first order dependence on both $\mathrm{H}_{2} \mathrm{O}_{2}$ and the surface area oxides (for example, the results of Lin and Gurol (1998), Valentine and Wang (1998), Teel et al (2007)). In the current study, a first order dependence of the $\mathrm{H}_{2} \mathrm{O}_{2}$ loss rate on $\left[\mathrm{H}_{2} \mathrm{O}_{2}\right]$ was also observed in all experiments (Table 1 and Figure 2A). As such, the rate of $\mathrm{H}_{2} \mathrm{O}_{2}$ loss in the aquifer materials systems can be described as:

$$
\frac{d\left[\mathrm{H}_{2} \mathrm{O}_{2}\right]}{d t}=-\mathrm{k}_{\mathrm{obs}} \times\left[\mathrm{H}_{2} \mathrm{O}_{2}\right]=-\left(\mathrm{k}_{\mathrm{Fe}-\mathrm{ox}} \times[\mathrm{Fe}-\mathrm{ox}]+\mathrm{k}_{\mathrm{Mn}-\mathrm{ox}} \times[\mathrm{Mn}-\mathrm{ox}]\right) \times\left[\mathrm{H}_{2} \mathrm{O}_{2}\right]
$$

In this expression, the rate constants for the reactions between $\mathrm{H}_{2} \mathrm{O}_{2}$ and iron and manganese oxides (i.e., Fe-ox and $\mathrm{Mn}$-ox) are $\mathrm{k}_{\mathrm{Fe}-\mathrm{ox}}$ and $\mathrm{k}_{\mathrm{Mn} \text {-ox }}$, respectively. Because $\mathrm{H}_{2} \mathrm{O}_{2}$ decomposition is a surface-catalyzed process, [Fe-ox] and [Mn-ox] in equation (3) should represent the concentration of Fe and Mn accessible at the surface. This is not necessary the same as the bulk concentration of Fe and Mn that would be measured by digesting aquifer materials sample with a strong acid. However, it is unlikely that there would be a unique, characteristic surface concentration of $\mathrm{Fe}$ and $\mathrm{Mn}$ in a heterogeneous aquifer materials sample, in which different grains of the sediment may be different mineral phases, or present different crystallographic faces. Accordingly, a least-square multiple regression was performed on the mass-normalized value of $\mathrm{k}_{\mathrm{obs}}\left(\mathrm{hr}^{-1} \mathrm{~g}^{-1}\right)$, [total-Mn] and [total-Fe] (mg/g) to obtain $\mathrm{k}_{\mathrm{Fe}-\mathrm{ox}}$ and $\mathrm{k}_{\mathrm{Mn}-\mathrm{ox}}$ in equation (3). This regression yielded $\mathrm{k}_{\mathrm{Fe}-\mathrm{ox}}=$ $-0.005 \pm 0.010\left(\mathrm{hr}^{-1} \mathrm{mg}^{-1}\right), \mathrm{k}_{\mathrm{Mn}-\mathrm{ox}}=2.900 \pm 0.335\left(\mathrm{hr}^{-1} \mathrm{mg}^{-1}\right)$, and an $\mathrm{r}^{2}$ value for the regression of 0.95 .

Independent linear regressions between the mass-normalized $\mathrm{k}_{\mathrm{obs}}$ and either [total-Fe] or [total-Mn] were also performed. The results of the regressions showed a weak correlation between $\mathrm{k}_{\mathrm{obs}}$ and [total-Fe] (i.e., $\mathrm{k}_{\mathrm{obs}}=(0.056 \pm 0.02) \times$ [total-Fe], $\left.\mathrm{r}^{2}=0.47\right)$, and a relatively strong correlation between $\mathrm{k}_{\mathrm{obs}}$ and [total-Mn] (i.e., $\mathrm{k}_{\mathrm{obs}}=(2.780 \pm 0.218) \times$ [total-Mn], $\mathrm{r}^{2}=0.95$ ) (Figure $3 \mathrm{~A}$ and $3 \mathrm{~B}$ ). Furthermore, the $\mathrm{k}_{\mathrm{Mn} \text {-ox }}$ value obtained from the linear regression (i.e., $2.780 \pm 0.218 \mathrm{hr}^{-1} \mathrm{mg}^{-1}$ ) was nearly identical to the value obtained from the least-square multiple regression (i.e., $2.900 \pm 0.335 \mathrm{hr}^{-1} \mathrm{mg}^{-1}$ ), indicating that the $\mathrm{H}_{2} \mathrm{O}_{2}$ loss rate in aquifer materials systems could be described without including loss of $\mathrm{H}_{2} \mathrm{O}_{2}$ on the iron oxides. This result suggests that the manganese oxides are much more important than the iron oxides to $\mathrm{H}_{2} \mathrm{O}_{2}$ decomposition in aquifer materials systems, despite the fact that the aquifer materials contained 16 to 185 times more Fe than Mn (Table 2). 
No clear correlation was observed between the stoichiometric efficiency (E) and [total-Fe] (Figure 3C). In contrast, the efficiency was inversely proportional to [total-Mn], with samples having [total-Mn] above $200 \mathrm{mg} / \mathrm{kg}$ exhibiting efficiencies lower than $0.03 \%$ (Figure 1S B), while those having [total-Mn] less than $200 \mathrm{mg} / \mathrm{kg}$ exhibited efficiencies that ranged from $0.036 \%$ to $0.28 \%$ (Figure 3D). The trend between $\mathrm{E}$ and [total-Mn] is consistent with the fact that ${ }^{\circ} \mathrm{OH}$ is not produced when $\mathrm{H}_{2} \mathrm{O}_{2}$ is decomposed on manganese oxides (Petigara et al., 2002; Furman et al.,2009).

In brief, the above analysis indicates that in aquifer materials systems, both the rates of $\mathrm{H}_{2} \mathrm{O}_{2}$ decomposition and stoichiometric efficiency are correlated with [total-Mn]. Therefore, the Mn content of aquifer samples might be used to make a preliminary comparison of the kinetics and efficiency of $\mathrm{H}_{2} \mathrm{O}_{2}$-based ISCO systems for different for aquifer materials.

Previous research indicated that, in addition to manganese and iron oxides, natural organic matter could also affect $\mathrm{H}_{2} \mathrm{O}_{2}$ decomposition, because natural organic matter associates with the surface of aquifer materials and directly affects their reactivity toward $\mathrm{H}_{2} \mathrm{O}_{2}$ decomposition. The presence of natural organic matter has the potential to decreases stoichiometric efficiency because it can act either as an ${ }^{\circ} \mathrm{OH}$ scavenger or as an absorptive phase that slows contaminant oxidation by preventing the ${ }^{\circ} \mathrm{OH}$ from reacting with the contaminant. There is, however, no consensus observation on the effect of natural organic matter on the rate of $\mathrm{H}_{2} \mathrm{O}_{2}$ decomposition in soils. Valentine and Wang (1998), Crimi and Siegrist (2005) and Bissey et al. (2006) reported that the rate of $\mathrm{H}_{2} \mathrm{O}_{2}$ decomposition was inversely correlated with the amount of organic matter. In contrast, $\mathrm{Xu}$ and Thomson (2010) observed that materials with high organic carbon content were more reactive with $\mathrm{H}_{2} \mathrm{O}_{2}$. Regarding stoichiometric efficiency, Valentine and Wang (1998) showed that addition of humic acid to the goethite $/ \mathrm{H}_{2} \mathrm{O}_{2}$ system resulted in an overall increase in stoichiometric efficiency. A similar efficiency enhancement was reported by Huling et al. (2001), who observed that a soil slurry that had been amended with peat was more effective than the original counterpart in activating $\mathrm{H}_{2} \mathrm{O}_{2}$. In contrast, Petigara et al. (2002) reported that low 'OH yields were associated with soils that contained more organic matter. In our study, there was no clear correlation between organic carbon content (TOC in Table 2) and $\mathrm{k}_{\mathrm{obs}}$ or $\mathrm{E}$ (Figure S1 A and D in the supporting information section).

\subsection{Stoichiometric efficiency enhancement by citrate-bicarbonate-dithionite extraction}

Relatively low stoichiometric efficiencies were observed with iron oxides (especially amorphous iron oxide, section 3.1.a.) and with aquifer materials that contained high concentrations of manganese oxides (section 3.1.b.). We hypothesized that removing these oxides would improve ${ }^{\circ} \mathrm{OH}$ yield in the aquifer material systems. To test this hypothesis, 6 aquifer samples (CADIR, CADOU, AWBPH, AFTCS, WYLAM, and WYSAN) were treated with citrate-bicarbonate-dithionite (CBD) solution to remove iron and manganese oxide coatings and discrete particles attached to the surface of aquifer materials. The amount of CBD-extractable $\mathrm{Fe}$ and $\mathrm{Mn}$ in these materials is reported in Table 2 as CBD-Fe and CBD-Mn.

The rates of $\mathrm{H}_{2} \mathrm{O}_{2}$ loss were much slower on the CBD-treated samples than on the original counterparts (Figure 4A). Moreover, CBD-treated samples were more effective in converting $\mathrm{H}_{2} \mathrm{O}_{2}$ into ${ }^{\circ} \mathrm{OH}$ (Figure 4B). The extent of the improvement in stoichiometric efficiency varied among samples. For example, the CBD-treated SDIR9 sample $(\mathrm{E}=0.15 \pm$ $0.01 \%)$ was only 1.3 times more effective than the original SDIR9 sample $(\mathrm{E}=0.11 \pm$ $0.02 \%)$. In contrast, the CBD-treated AFTCS, WYSAN and WYLAM samples were 10 to 40 times more effective. The extent of improvement in ${ }^{\circ} \mathrm{OH}$ yield appeared to correlate with the fraction of Mn removed by CBD treatment (over 50\% of the total Mn in AFTCS, WYSAN and WYLAM was CBD-extractable Mn, Table 2). A previous study (Miller and 
Valentine, 1995) demonstrated that removing Mn-oxide by treating a sediment sample with $\mathrm{NH}_{2} \mathrm{OH} / \mathrm{HCl}$ also increased the stoichiometric efficiency by over 3 times. Although injecting $\mathrm{CBD}$ or $\mathrm{NH}_{2} \mathrm{OH} / \mathrm{HCl}$ solution into the subsurface is unlikely to be practical, employing conditions that favor the dissolution of iron and manganese oxides, such as adjusting redox conditions to favor reductive dissolution or adding a strong chelating agent during soil washing, may enhance ${ }^{\circ} \mathrm{OH}$ yield in $\mathrm{H}_{2} \mathrm{O}_{2}$-based ISCO treatment systems.

\subsection{Effect of dissolved silica on the rate of $\mathrm{H}_{2} \mathrm{O}_{2}$ decomposition and stoichiometric efficiency with aquifer materials}

In $\mathrm{H}_{2} \mathrm{O}_{2}$-based ISCO, the rate of $\mathrm{H}_{2} \mathrm{O}_{2}$ decomposition and the yield of ' $\mathrm{OH}$ are controlled not only by the properties of the aquifer materials but also by the groundwater composition (e.g., $\mathrm{pH}$, the presence of naturally occurring solutes, such as dissolved silica, bicarbonate or phosphate). Therefore, understandings of the effect of different solutes on the reactivity of aquifer materials with $\mathrm{H}_{2} \mathrm{O}_{2}$ are important to predict kinetics and efficiency of $\mathrm{H}_{2} \mathrm{O}_{2}$ activation in ISCO.

In a previous study (Pham et al., 2012), we reported that dissolved $\mathrm{SiO}_{2}$ slows the rate of $\mathrm{H}_{2} \mathrm{O}_{2}$ decomposition on iron- and manganese-containing minerals, because dissolved $\mathrm{SiO}_{2}$ adsorbs onto mineral surfaces and decreases their catalytic reactivity. To determine whether dissolved $\mathrm{SiO}_{2}$ has a similar effect on $\mathrm{H}_{2} \mathrm{O}_{2}$ activation in ISCO systems, we measured the rate of $\mathrm{H}_{2} \mathrm{O}_{2}$ decomposition and ${ }^{\circ} \mathrm{OH}$ yield for authentic aquifer minerals in the presence and absence of added dissolved $\mathrm{SiO}_{2}$. Our results indicated that $2 \mathrm{mM}$ of dissolved $\mathrm{SiO}_{2}$ slowed $\mathrm{H}_{2} \mathrm{O}_{2}$ decomposition by approximately 25 to $60 \%$ (Figure 5). For the three samples exhibiting the highest stoichiometric efficiencies (i.e., CADIR, CAROL and KENTK), the presence of dissolved $\mathrm{SiO}_{2}$ did not affect the efficiency (inset of Figure 5). These results are consistent with, but extend our previous findings about the role of silica, suggesting that dissolved $\mathrm{SiO}_{2}$ in groundwater is beneficial for $\mathrm{H}_{2} \mathrm{O}_{2}$-based ISCO because it can increase $\mathrm{H}_{2} \mathrm{O}_{2}$ persistence in the subsurface. Furthermore, injecting dissolved $\mathrm{SiO}_{2}$ together with $\mathrm{H}_{2} \mathrm{O}_{2}$ could further improve $\mathrm{H}_{2} \mathrm{O}_{2}$ persistence, without compromising ${ }^{\circ} \mathrm{OH}$ yield. Compared with phosphate and carbonate, dissolved $\mathrm{SiO}_{2}$ has a potential to be a better $\mathrm{H}_{2} \mathrm{O}_{2}$-stabilizing agent because it neither stimulates bacterial growth (as does phosphate) nor forms precipitates (as does carbonate). The precipitation of carbonate minerals (e.g., $\mathrm{CaCO}_{3}$ and $\mathrm{MgCO}_{3}$ ) could pose problems to efforts to maintain constant carbonate concentrations and to avoid aquifer clogging.

\section{Conclusions}

The findings presented in this study have important implications for the design and operation of $\mathrm{H}_{2} \mathrm{O}_{2}$-based in situ chemical oxidation systems employed for soil and groundwater remediation. They also provide insights into the design of better iron catalysts for $e x$ situ waste treatment systems. Major findings and their implications are summarized below:

1. In both iron-containing mineral and aquifer materials systems, the solids that were more reactive in catalyzing $\mathrm{H}_{2} \mathrm{O}_{2}$ decomposition exhibited lower stoichiometric efficiency. This observation suggested that in heterogeneous Fenton systems, fast $\mathrm{H}_{2} \mathrm{O}_{2}$ disappearance is not always coupled with rapid contaminant oxidation. Therefore, to evaluate the efficiency of a heterogeneous Fenton system, both kinetics of $\mathrm{H}_{2} \mathrm{O}_{2}$ decomposition and stoichiometric efficiency should be considered.

2. The coordination of iron in the solid affects its reactivity with respect to $\mathrm{H}_{2} \mathrm{O}_{2}$ activation. Due to the coordination between $\mathrm{Fe}$ and $\mathrm{Al}$ and/or $\mathrm{Si}$, surfaces 
comprising mixed phases of $\mathrm{Fe}, \mathrm{Al}$ and $\mathrm{Si}$ oxides (e.g., iron-containing aluminosilicate minerals, FeSi-ox and FeAlSi-ox catalysts) were more effective in converting $\mathrm{H}_{2} \mathrm{O}_{2}$ into ${ }^{\circ} \mathrm{OH}$ than the surfaces of pure iron oxides. Therefore, silicaand alumina-containing iron oxides have the potential to be more effective than iron oxides in ex situ treatment systems.

3. Surfaces that were more reactive with $\mathrm{H}_{2} \mathrm{O}_{2}$ tend to be less effective in producing $\cdot \mathrm{OH}$. Although fast $\mathrm{H}_{2} \mathrm{O}_{2}$ decomposition expedites contaminant removal, this might compromise $\mathrm{OH}$ yield which, in turn, requires disproportionately more $\mathrm{H}_{2} \mathrm{O}_{2}$. This should be considered in the design of catalysts for ex situ treatment systems.

4. Aquifer materials that contain high concentrations of manganese oxides decomposed $\mathrm{H}_{2} \mathrm{O}_{2}$ at a faster rate but generated less ' $\mathrm{OH}$ (i.e., they had a lower stoichiometric efficiency). The strong correlation between Mn content and $\mathrm{H}_{2} \mathrm{O}_{2}$ loss rate and ${ }^{\circ} \mathrm{OH}$ yield suggests that the amount of $\mathrm{Mn}$ in aquifer materials could serve as a proxy for predicting $\mathrm{H}_{2} \mathrm{O}_{2}$ activation rates and contaminant oxidation efficiency. Additional research with more aquifer materials is needed to assess the predictive strength of this correlation.

5. Removing free iron and manganese oxides from aquifer materials slows $\mathrm{H}_{2} \mathrm{O}_{2}$ decomposition and increases ${ }^{\circ} \mathrm{OH}$ yield. Although the addition of citratebicarbonate-dithionite solution into soil and groundwater is unlikely to be practical, other approaches that remove manganese and iron oxides could enhance the efficiency of $\mathrm{H}_{2} \mathrm{O}_{2}$-based ISCO.

6. In aquifer materials systems, dissolved $\mathrm{SiO}_{2}$ slows the $\mathrm{H}_{2} \mathrm{O}_{2}$ decomposition rate without affecting 'OH yields. Therefore, during ISCO remediation, dissolved $\mathrm{SiO}_{2}$ could be injected into the subsurface to increase the persistence of $\mathrm{H}_{2} \mathrm{O}_{2}$. Dissolved $\mathrm{SiO}_{2}$ is inexpensive and benign and could replace phosphate or carbonate as a $\mathrm{H}_{2} \mathrm{O}_{2}$ stabilizing reagent. In ex situ treatment systems that employ iron catalysts, dissolved silica might result in gradual loss in catalyst reactivity.

\section{Supplementary Material}

Refer to Web version on PubMed Central for supplementary material.

\section{Acknowledgments}

This research was funded by the U.S. National Institute for Environmental Health Sciences (NIEHS) Superfund Basic Research Program (Grant P42 ES004705). A.L.P. was supported in part by Vietnam Education Foundation (VEF). The authors would like to thank collaborators at Arizona State University, Lawrence Berkeley National Laboratory and the University of Kentucky for providing aquifer materials, and Dr. Peter Nico at Lawrence Berkeley National Laboratory for providing iron oxide-coated sand. We thank Thomas Bruton for providing constructive comments.

\section{References}

Bissey LL, Smith JL, Watts RJ. Soil organic matter-hydrogen peroxide dynamics in the treatment of contaminated soils and groundwater using catalyzed $\mathrm{H} 2 \mathrm{O} 2$ propagations (modified Fenton's reagent). Water Res. 2006; 40:2477-2484. [PubMed: 16815526]

Crimi ML, Siegrist RL. Factors affecting effectiveness and efficiency of DNAPL destruction using potassium permanganate and catalyzed hydrogen peroxide. J. Environ. Eng. 2005; 131:1724-1732.

Eisenberg G. Colorimetric determination of hydrogen peroxide. Ind. Eng. Chem., Anal. Ed. 1943; $15: 327-328$. 
Furman O, Laine DF, Blumenfeld A, Teel AL, Shimizu K, Cheng IF, Watts RJ. Enhanced reactivity of superoxide in water-solid matrices. Environ. Sci. Technol. 2009; 43:1528-1533. [PubMed: 19350930]

Huang H-H, Lu M-C, Chen J-N. Catalytic decomposition of hydrogen peroxide and 2-chlorophenol with iron oxides. Water Res. 2001; 35:2291-2299. [PubMed: 11358310]

Huling SG, Arnold RG, Sierka RA, Miller MR. Influence of peat on Fenton oxidation. Water Res. 2001; 35:1687-1694. [PubMed: 11329670]

Huling, SG.; Pivetz, BE. [(Accessed August 24, 2012)] In-situ chemical oxidation. U.S. Environmental Protection Agency Engineering Issue. 2006. http://www.epa.gov/ada/gw/pdfs/ insituchemicaloxidation_engineering_issue.pdf.

Keeling JL, Raven MD, Gates WP. Geology and characterization of two hydrothermal nontronites from weathered metamorphic rocks at the Uley Graphite Mine, South Australia. Clays Clay Miner. 2000; 48:537-548.

Krembs FJ, Siegrist RL, Crimi ML, Furrer RF, Petri BG. ISCO for groundwater remediation: analysis of field applications and performance. Ground Water Monitoring \& Remediation. 2010; 30:42-53.

Kunze, GW.; Dixon, JB. Pretreatment for mineralogical analysis. In: Klute, A., editor. Method of soil analysis: part 1 - physical and mineralogical methods. 1986. p. 97-99.

Kwan WP, Voelker BM. Decomposition of hydrogen peroxide and organic compounds in the presence of dissolved iron and ferrihydrite. Environ. Sci. Technol. 2002; 36:1467-1476. [PubMed: 11999052]

Lim H, Lee J, Jin S, Kim J, Yoon J, Hyeon T. Highly active heterogeneous Fenton catalyst using iron oxide nanoparticles immobilized in alumina coated mesoporous silica. Chem.Commun. 2006; 4:463-465.

Lin S-S, Gurol MD. Catalytic Decomposition of hydrogen peroxide on iron oxide: Kinetics, Mechanism, and Implications. Environ. Sci. Technol. 1998; 32:1417-1423.

Lou M, Bowden D, Brimblecombe P. Catalytic property of Fe-Al pillared clay for Fenton oxidation of phenol by $\mathrm{H}_{2} \mathrm{O}_{2}$. Applied Catal. B: Environ. 2009; 85:201-206.

Matta R, Hanna K, Chiron S. Fenton-like oxidation of 2,4,6-trinitrotoluene using different iron minerals. Sci. Tot. Environ. 2007; 385:242-251.

Miller CM, Valentine RL. Hydrogen peroxide decomposition and quinoline degradation in the presence of aquifer material. Water Res. 1995; 29:2353-2359.

Miller CM, Valentine RL. Mechanistic studies of surface catalyzed $\mathrm{H}_{2} \mathrm{O}_{2}$ decomposition and contaminant degradation in the presence of sand. Water Res. 1999; 33:2805-2816.

Nico PS, Stewart BD, Fendorf S. Incorporation of oxidized uranium into Fe (hydr)oxides during Fe(II) catalyzed remineralization. Environ. Sci. Technol. 2009; 43:7391-7396. [PubMed: 19848151]

Petigara BR, Blough NV, Mignerey AC. Mechanisms of hydrogen peroxide decomposition in soils. Environ. Sci. Technol. 2002; 36:639-645. [PubMed: 11878378]

Pham ALT, Lee C, Doyle FM, Sedlak DL. A silica-supported iron oxide catalyst capable of activating hydrogen peroxide at neutral pH values. Environ. Sci. Technol. 2009; 43:8930-8935. [PubMed: 19943668]

Pham ALT, Doyle FM, Sedlak DL. Inhibitory effect of dissolved silica on $\mathrm{H}_{2} \mathrm{O}_{2}$ decomposition by iron(III) and manganese(IV) oxides: implication for $\mathrm{H}_{2} \mathrm{O}_{2}$ based in situ chemical oxidation. Environ. Sci. Technol. 2012; 46:1055-1062. [PubMed: 22129132]

Ravikumar JX, Gurol MD. Chemical oxidation of chlorinated organics by hydrogen peroxide in the presence of sand. Environ.Sci. Technol. 1994; 28:394-400. [PubMed: 22165872]

Valentine RL, Wang HCA. Iron oxide surface catalyzed oxidation of quinoline by hydrogen peroxide. J. Environ. Eng. 1998; 124:31-38.

Schwertmann, U.; Cornell, RM. Iron oxides in the laboratory: preparation and characterization. WileyVCH Publishers; Weinheim, Germany: 2006.

Tamura H, Goto K, Yotsuyanagi T, Nagayama M. Spectrophotometric determination of iron(II) with 1,10-phenanthroline in the presence of large amounts of iron(III). Talanta. 1974; 21:314-318. [PubMed: 18961462] 
Taujale S, Zhang H. Impact of interactions between metal oxides to oxidative reactivity of manganese dioxide. Environ. Sci. Technol. 2012; 46:2764-2771. [PubMed: 22309023]

Teel AL, Finn DD, Schmidt JT, Cutler LM, Watts RJ. Rates of trace mineral-catalyzed decomposition of hydrogen peroxide. J. Environ. Eng. 2007; 133:853-858.

Watts RJ, Finn DD, Cutler LM, Schmidt JT, Teel AL. Enhanced stability of hydrogen peroxide in the presence of subsurface solids. J. Contam. Hydrol. 2007; 91:312-326. [PubMed: 17196706]

$\mathrm{Xu}$ X, Thomson NR. Hydrogen peroxide persistence in the presence of aquifer materials. Soil and Sediment Contamination: An International Journal. 2010; 19:602-616. 


\section{Highlights}

- $\mathrm{H}_{2} \mathrm{O}_{2}$ loss and $\cdot \mathrm{OH}$ production catalyzed by iron-containing solids were studied.

- Solids that were more reactive with $\mathrm{H}_{2} \mathrm{O}_{2}$ exhibiting lower ' $\mathrm{OH}$ production.

- Surface iron and manganese oxides are detrimental for ${ }^{\circ} \mathrm{OH}$ production.

- Removing ineffective oxides enhanced the ${ }^{\circ} \mathrm{OH}$ production efficiency.

- Dissolved silica slowed the rate of $\mathrm{H}_{2} \mathrm{O}_{2}$ loss. 

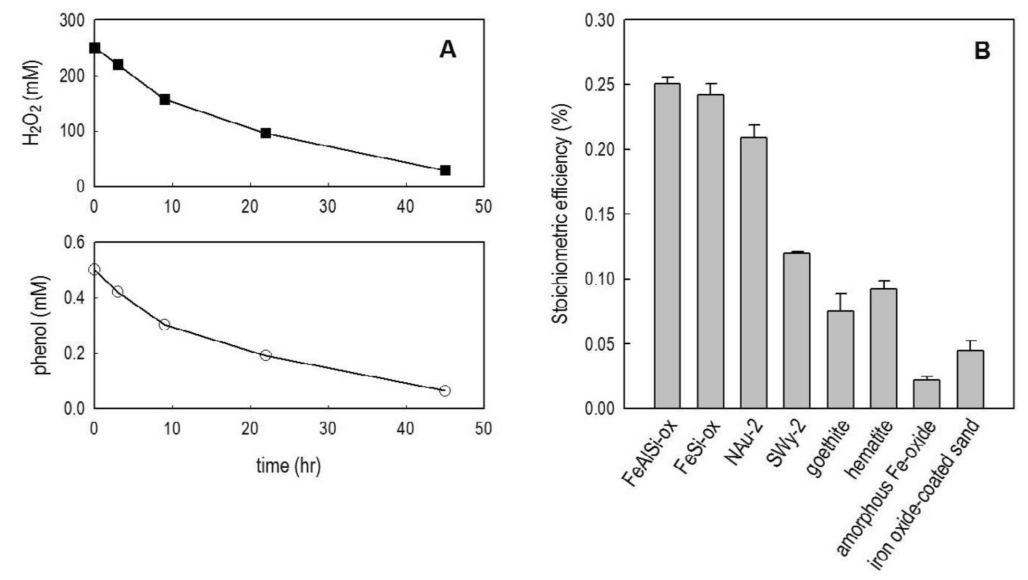

Figure 1.

(A): A representative example of $\mathrm{H}_{2} \mathrm{O}_{2}$ decomposition and phenol transformation. [NAu-2] $=5 \mathrm{~g} / \mathrm{L}, \mathrm{pH}=8.4 \pm 0.1$, [borate] $=2 \mathrm{mM}$. (B): Stoichiometric efficiency $(\Delta[$ phenol] $/$ $\left.\Delta\left[\mathrm{H}_{2} \mathrm{O}_{2}\right] \times 100 \%\right)$ with different iron-containing minerals. $\left[\mathrm{H}_{2} \mathrm{O}_{2}\right]_{0}=250 \mathrm{mM}$, [phenol $]_{0}=$ $0.5 \mathrm{mM},[\mathrm{FeSi}$-ox $]=[\mathrm{FeAlSi}-\mathrm{ox}]=10 \mathrm{~g} / \mathrm{L},[\mathrm{NAu}-2]=5 \mathrm{~g} / \mathrm{L},[\mathrm{Swy}-2]=10 \mathrm{~g} / \mathrm{L}$, [hematite $]=$ $[$ goethite $]=10 \mathrm{~g} / \mathrm{L},[\mathrm{FeOOH}]=1 \mathrm{~g} / \mathrm{L},[\mathrm{Fe}-$ coated sand $]=10 \mathrm{~g} / \mathrm{L}, \mathrm{pH}=8.4 \pm 0.1$. 

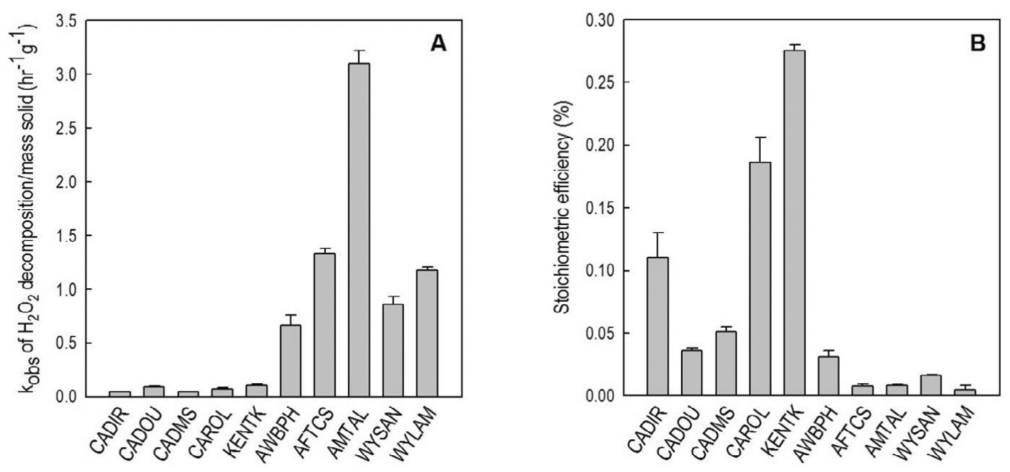

Figure 2.

Mass-normalized observed-first order rate constants for $\mathrm{H}_{2} \mathrm{O}_{2}$ decomposition (A) and stoichiometric efficiency $(\mathrm{B})$ with aquifer materials. $\left[\mathrm{H}_{2} \mathrm{O}_{2}\right]_{0}=250 \mathrm{mM}$, [phenol $]_{0}=0.5$ $\mathrm{mM}$, [solid] was either $150 \mathrm{~g} / \mathrm{L}$ (for CADIR, CADOU and CADMS) or $50 \mathrm{~g} / \mathrm{L}$ (for all other aquifer materials), [borate] $=10 \mathrm{mM}, \mathrm{pH}=8.2-8.7$, except in experiments with KENTK, in which the $\mathrm{pH}$ was 7.2 (see Table 2 ). The observed-first order rate constants $\left(\mathrm{k}_{\mathrm{obs}}\right)$ were obtained by fitting the experimental data to the first order decay reaction rate law. The $\mathrm{r}^{2}$ values of the fittings were always $r^{2}>0.99$. 


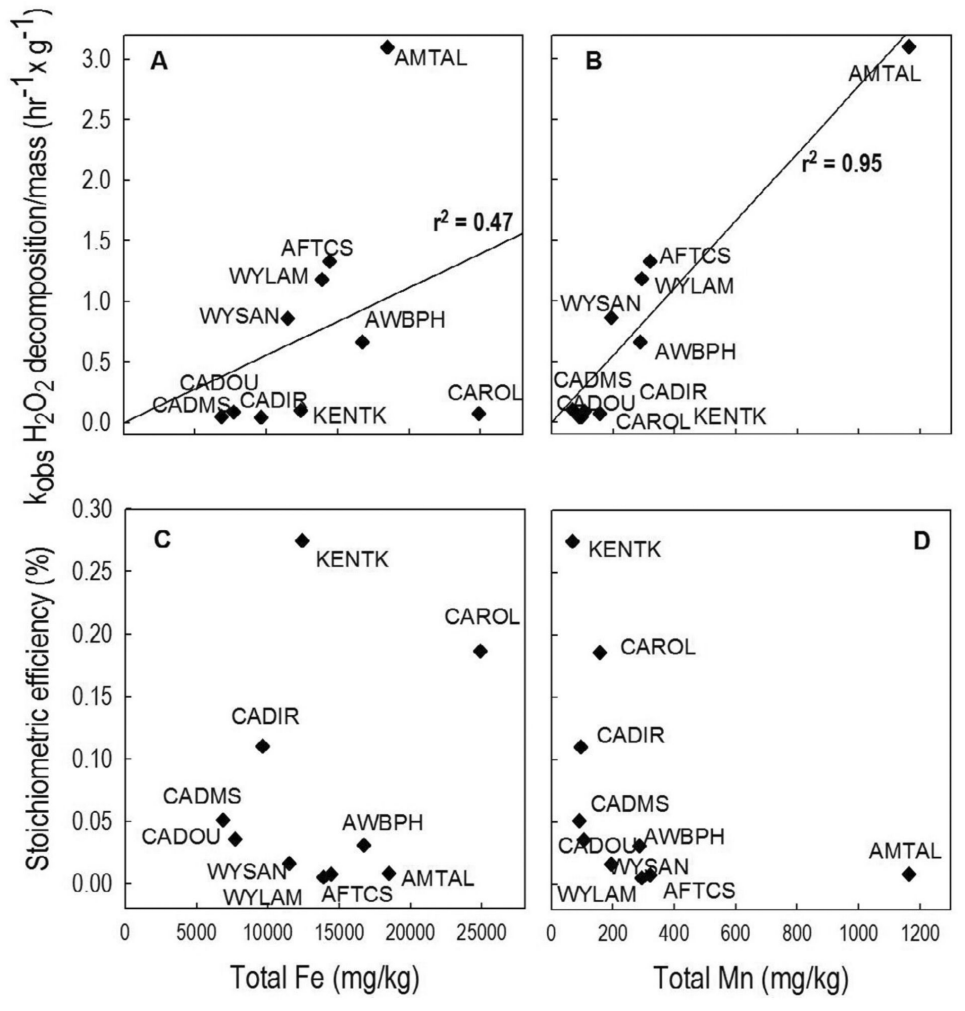

Figure 3.

Correlation between $\mathrm{H}_{2} \mathrm{O}_{2}$ decomposition rate (A and $\mathrm{B}$ ), stoichiometric efficiency ( $\mathrm{C}$ and $\mathrm{D})$ and the total $\mathrm{Fe}$ and $\mathrm{Mn}$ of aquifer samples. The top and bottom figures share the same $\mathrm{X}$ axis. 

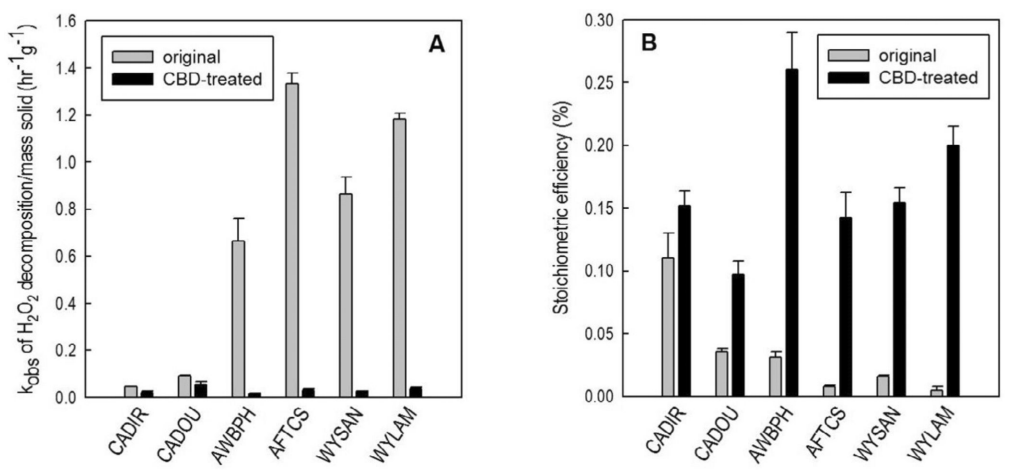

Figure 4.

Mass-normalized observed-first order rate constants for $\mathrm{H}_{2} \mathrm{O}_{2}$ decomposition (A) and stoichiometric efficiency (B) with original and CBD-treated aquifer materials. Experimental conditions were similar to those described in the capture of Figure 2. 


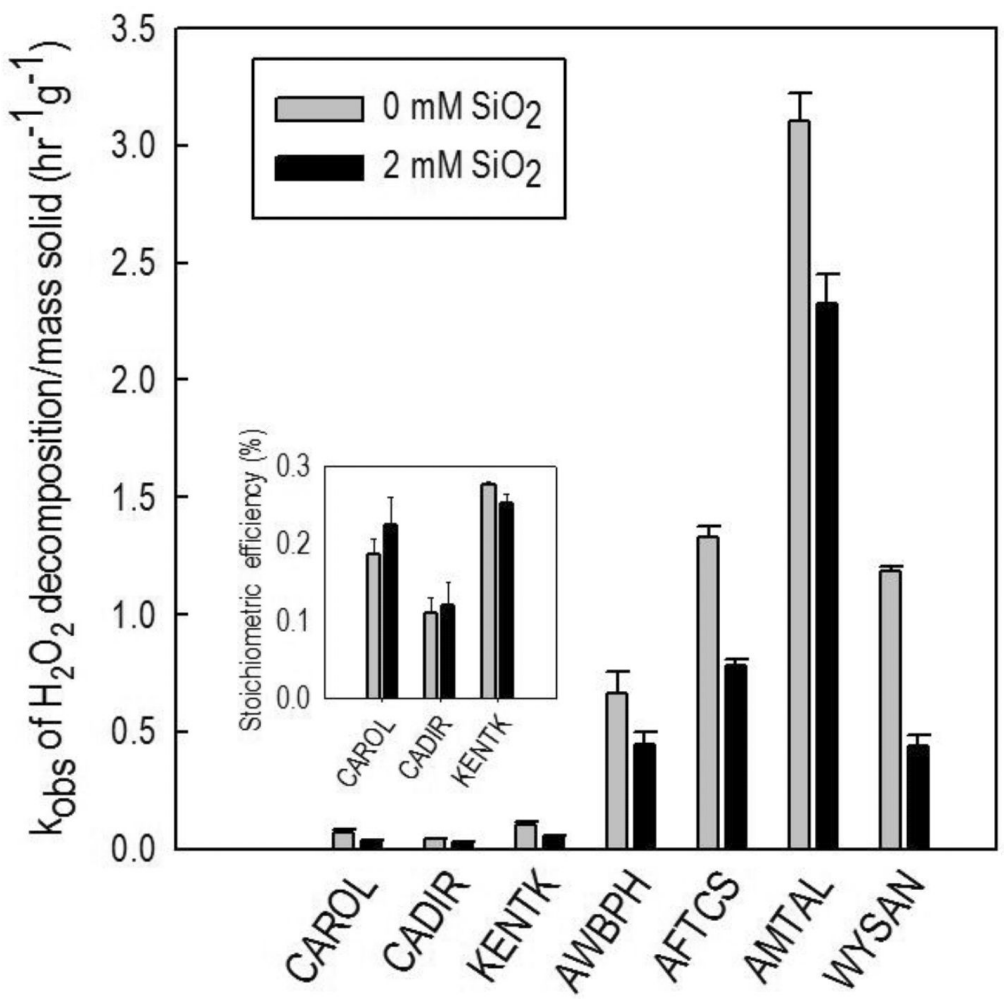

Figure 5.

Effect of dissolved $\mathrm{SiO}_{2}$ on the rate of $\mathrm{H}_{2} \mathrm{O}_{2}$ decomposition by aquifer materials and stoichiometric efficiency (inset). $\left[\mathrm{SiO}_{2}\right]=2 \mathrm{mM},\left[\mathrm{H}_{2} \mathrm{O}_{2}\right]_{0}=250 \mathrm{mM}$, [phenol $]_{0}=0.5 \mathrm{mM}$, [solid] was either $150 \mathrm{~g} / \mathrm{L}$ (SDIR9) or $50 \mathrm{~g} / \mathrm{L}$ (all other aquifer materials), [borate] $=10 \mathrm{mM}$, $\mathrm{pH}=8.2-8.5$. 


\section{Table 1}

Properties of iron-containing minerals and observed-first order rate constants for mineral-catalyzed $\mathrm{H}_{2} \mathrm{O}_{2}$ decomposition.

\begin{tabular}{lccc}
\hline Minerals & Surface area $\left(\mathbf{m}^{\mathbf{2}} / \mathbf{g}\right)$ & Iron content $(\mathbf{w t .} \%)$ & $\mathbf{k}_{\mathbf{o b s}} / \mathbf{m}^{\mathbf{2}}(\mathbf{b})(\boldsymbol{c})$ \\
\hline Goethite & 19 & $\left.62 . \mathbf{h r}^{-\mathbf{1}} \times \mathbf{m}^{-\mathbf{2}}\right)$ \\
Hematite & 30 & 70.0 & 0.015 \\
Amorphous Fe-oxide & 166 & $62.9^{(a)}$ & 0.032 \\
Swy-2 & 32 & 2.6 & 0.097 \\
NAu-2 & 69 & 26.2 & 0.022 \\
Iron oxide-coated sand & 5 & 1.0 & 0.012 \\
FeSi-ox & 521 & 12.3 & 0.199 \\
FeAlSi-ox & 423 & 10.9 & 0.007 \\
\hline
\end{tabular}

${ }^{\text {(a) }}$ Values were calculated based on the $\mathrm{FeOOH}$ formula.

${ }^{(b)}$ The observed-first order rate constants $\left(\mathrm{k}_{\mathrm{obs}}\right)$ were obtained by fitting the experimental data to the first order decay reaction rate law. The $\mathrm{r}^{2}$ values of the fittings were always $\mathrm{r}^{2}>0.99$.

${ }^{(c)}$ Rate constants were normalized by the total surface area of the solid used in the experiment. 
